\title{
2 The circumstances of crime and fear in public places
}

\section{A review of theories}

\author{
Vania Ceccato
}

\subsection{Introduction}

This chapter discusses the extant theories used to interpret the occurrence of crime and fear in public places, which are set out within the framework suggested in the previous chapter. The aim is to translate these theories into an integrated conceptual framework within which safety (crime and fear) in public environments can be examined. None of these theoretical perspectives is without criticism, and none has been explicitly developed for application to public places. This theoretical review is intended to support the analysis of the empirical research illustrated in the five cross-cutting themes of the book derived from a wide range of perspectives and disciplines. We begin by discussing the concept of public places in relation to the dynamics of urban crime and fear. Then, due to the range of theoretical approaches in the international literature, the chapter concentrates on those aspects considered salient to the major components of the book: the city environment, people's mobility, users' perspective, metrics of crime and fear and intervention.

\subsection{Public places and safety}

To be fully public, a public place must be safe. Public places are entities that are collectively shared. They can be an indoor or an outdoor area, more often publicly owned, to which anyone has access. ${ }^{1}$ They can take different shapes: from parks, streets and transit environments, to shopping malls or interstitial spaces, each one with its own design features. Public places may gather thousands of people (e.g., stadiums, airports, major central stations) or be desolate paths or empty stations. In either case, poor design can maximize crime opportunities or give users the notion that nobody is in control and, therefore, they are unsafe. Although it is difficult to make generalizations about safety in public places, the international literature on environmental criminology discussed in this chapter (e.g., Brantingham \& Brantingham, 1984; Eck, 1998; Sherman, Gartin, \& Buerger, 1989; Weisburd, 2015) demonstrates how to detect situational conditions that generate crime in several types of public places and ways to promote safety perceptions. In the next section we review 
environmental criminology theories that focus on the role of urban environment in crime and perceived safety.

\subsection{The urban environment}

Crime opportunities are influenced by the design of urban spaces and the way such spaces are arranged in the urban fabric. Thus, architects, planners and safety experts have an important role to play when a new public place is planned and safety guidelines are implemented. These experts decide details that affect types of facades, the height of walls, orientation of windows, garages, storage spaces and more, which, alone or together, impact the safety of the area. Brantingham and Brantingham (1995, p. 3) suggest that:

the urban settings that create crime and fear are human constructions ... homes, parks, factories, transport systems ... the ways in which we assemble these large building blocks of routine activity into the urban cloth can have an enormous impact on our fear levels and on the quantities, types and timing of crimes we suffer.

Indeed, crime opportunities are also a function of the density of buildings, layout of streets and entrances, the connection of backyards with the main streets, alleys, parking spaces, physical barriers between buildings and public places as well as modern security features (e.g., CCTV) that individually or together affect surveillance opportunities and allow guardianship. Guardianship is the process by which individuals function as effective informal crime prevention and control agents (Reynald, 2014) and is therefore key to the safety of an area. Yet, the risk of being victimized by a crime is also dependent on the overall context at work in a particular setting, at a particular time. Public places in inner city areas are peculiar places because they often concentrate risky facilities (Clarke \& Eck, 2007) at much higher ratios than anywhere else in the city. How these design features relate to the whole city, support accessibility and create feelings of territoriality while allowing surveillance and guardianship is largely illustrated in the literature (Armitage, 2018; Armitage \& Monchuk, 2011; Ceccato, 2012a, 2012b; Cozens \& Hillier, 2008; Cozens, 2011; Grönlund, 2012; Loukaitou-Sideris, 2012; Poyner, 1986, 1991, 2005).

\section{Urban design and safety: key concepts in a historical perspective}

Theories developed since the 1950s indicate the importance of the design of microspaces to the whole urban structure in creating opportunities/barriers for human activities, including crime. Some theories are particularly devoted to the understanding of how individuals shape different environments, how they are affected by them and are engaged in the (use and maintenance of) spaces as indicators of the quality of the area (Barker, 1968; Sommer, 1972; Thomlinson, 1969). 
It was not until the early 1970s that a more explicit set of design rules was developed to encourage monitoring of public spaces with the intention to reduce crime opportunities. One example was Crime Prevention Through Environmental Design (CPTED), introduced by criminologist C. Ray Jeffery in 1971. CPTED is defined as "the corrected design and the efficient use of the built environment that can lead to a reduction in fear of crime and crime incidents and to an improvement in quality of life" (Crowe, 2000). Jeffery's ideas-that the environment has an impact on crime-encountered great resistance, especially among criminologists who claimed he advocated for simplified extrapolations between the physical environment and human behavior (Jeffery, 1977).

Nearly at the same time, the architect Oscar Newman put forward the theory of "defensible space" (Newman, 1972) having clear similarities with Jeffery's CPTED. Defensible space is defined as an environment whose physical characteristics function to allow individuals to become key agents in ensuring their safety. Natural surveillance - a key concept in this model - involves ensuring clear sightlines by designing the "right" placement of physical features, such as windows. CPTED ideas started to attract more notice outside academia with the publication of the Design Guidelines for Creating Defensible Space by the National Institute of Law Enforcement and Criminal Justice (now the National Institute of Justice). What most people are unaware of is that, as early as the 1950s, similar ideas were developed in the United States linking the importance of the urban design to neighborhood quality. Elizabeth Wood, a housing advocate and planner in Chicago, urged planners to build small projects (instead of the tall structures considered modern at the time) and to incorporate shops, parks and even pubs to transform housing complexes into real neighborhoods. Wood's principles were never implemented according to the original intentions. Another pioneer was the journalist Jane Jacobs, who, in the 1960s and in the same vein as Woods, criticized the failure of design of public housing in the United States. Jacobs coined the iconic concept of "eyes on the street" (Jacobs, 1961), highlighting how urban design plays a crucial role in providing opportunities for surveillance, guardianship and crime prevention. For a street to be safe, Jacobs (1961, p. 35) wrote:

... there must be eyes on the street, eyes that belong to those we can call the natural owners of the street.

Promoting opportunities for surveillance is, of course, not automatically effective. Effectiveness here depends largely on the willingness and the ability of the individual in exercising guardianship. For example, according to Eck (2019), place managers are important because they can exercise control over users and in doing so contribute to the safety of the public space. Nowadays, "eyes" can be complemented by technologies that give expression to new ways of depicting what happens in public places, from surveillance to sousveillance (see Ceccato, 2019 and in this book, part "The metrics").

The interrelations between urban design and an individual's willingness and ability to exercise control over an area were also indicated by research in the 
United Kingdom by the geographer Alice Coleman (Coleman, 1985). Coleman carried out an extensive study showing the impact of modernistic large-scale social housing projects on safety. The author showed how the scale and size of the built environment were essential parts of the problem: the size of the building lot, the number of blocks, the number of dwellings per block, the number of floors and the number of households around the same stairwell. Her study was controversial and, among other things, was criticized for lack of attention to social factors interacting with the physical (Mikellides, 2007) as well as for its methodology (Hillier, 1986).

In the late 1980s, safety and security guidelines were created in the UK for the certification of new residential areas. A similar model of certification was also developed in the Netherlands. The ideas of the Dutch model derived in part from the principles of living structure as a "pattern language", created by Christopher Alexander and others (Alexander, Ishikawa, \& Silverstein, 1977). This model describes methods for constructing "practical, safe, and attractive designs at every scale" and later inspired the "secured by design" model implemented in the Netherlands in the 1990s (Jongejan \& Woldendorp, 2013).

In the decades that followed, both research and practice have moved away from the strict link between an area's physical environment and safety and focused more on its social dimension. In the United States, this approach was called the "second generation of CPTED" and has evolved in different ways. On one hand, this development has led to the engagement of individuals in participatory plans, in particular those incorporating different users' perspectives on urban spaces, such as women and children. Safety walks, especially women's safety walks, are an example of these methods (Whitzman, 2007; Whitzman, Shaw, Andrew, \& Travers, 2009). Similarly, another practical example of second generation CPTED was reported by Gregory Saville and team (2009), who implemented planning safety models combining community development strategies and crime prevention programs in neighborhoods (see also Saville, 2018). According to Armitage and Ekblom (2019), Saville is a pioneer of second generation CPTED that stresses the importance of public participation in the processes of evolving safer, more sociable urban places. His concept builds on crime prevention through urban design principles, but emphasizing the role that communities can play to create safe and sustainable communities. A step forward is proposed by Mihinjac and Saville (2019) with the "CPTED third generation", a framework that integrates issues of safety, public health and sustainability.

On the other hand, around the world, current ways of implementing CPTED ideas in municipal planning have often involved consulting firms delivering proposals for urban design as well as integrated planning strategies that combine evaluations of the physical and social environments with participatory schemes, involving residents and stakeholders (see for example Gray \& Novacevski, 2015; Jongejan \& Woldendorp, 2013). This development has also witnessed an increasing commodification of security (Goold, Loader, \& Thumala, 2010) that can take different forms, from an industry that survives by delivering a range of (often untested) products and security gadgets (e.g., CCTV cameras, drones, 
security windows), to organizations that provide security standards and certifications, not infrequently recycled models from the original first generation of CPTED principles. This commodification has been extreme, and gated communities have turned into permanent housing and safety solutions in crime-ridden countries (Asiedu \& Arku, 2009; Branic \& Kubrin, 2018; Breetzke, Landman, \& Cohn, 2014; Chase, 2008; Grundström, 2018; Lemanski, 2006; Wilson, 1999) and have found their way into Europe (Grundström, 2018) and elsewhere (Tedong, Grant, \& Abd Aziz, 2014).

Partnership initiatives between the public and private sectors (e.g., Building Improvement Districts (BIDs)) have become an integral part of the model of delivering safety guidelines and strategies in planning schemes around the world (Clutter, Henderson, \& Haberman, 2019; McCarthy \& Doyle, 2011; Symes \& Steel, 2003). In smaller communities, policing and crime prevention initiatives, in the absence of the police forces, have involved NGOs, security companies and the voluntary sector to tackle safety problems (Kang, 2011; Uhnoo \& Hansen Löfstrand, 2018; Yarwood \& Edwards, 1995). It is unclear, however, whether this development can continue to ensure safety as a human right and not only for those who can afford it.

In summary, the planning models that have flourished in the past 20 years are filling up the void in knowledge (and action) of researchers and in particular of public actors (namely, between planners, police officers, policymakers, engineers and the like) in recognizing the importance of links between safety and the physical and social environments.

\section{Safety and neigbborbood context}

The causes of crime have traditionally been attributed much more to the characteristics of the individual than to the situational conditions where crime occurs. The first school of knowledge that pointed to the role of society in crimemore explicitly neighborhoods-were researchers Shaw and McKay (Shaw \& McKay, 1942) in the United States. In the early 1930s, they suggested a link between poverty, housing mobility, weak social control and crime in some areas of Chicago. It was believed that social control in some areas was the key to making a residential area safe. (Social control can be interpreted as the process of a group regulating itself according to its beliefs, principles and values.) Socially disorganized neighborhoods (neighborhoods with high housing and business turnover, lack of community agency and participation) typically have more crime and less social control. Social disorganization theory and its modern developments (Kornhauser, 1978; Sampson, Raudenbush, \& Earls, 1997; Shaw \& McKay, 1942) have provided the theoretical underpinning for many studies that focus on the impact of neighborhood characteristics on crime as well as key indications on how to prevent crime.

When residents and stakeholders are not willing to join forces to prevent petty crimes, a sense of disorder in society develops. In particular disadvantaged areas, this process reproduces itself-disorder causes crime, crime in turn creates 
fear-leading to a spiral of decay. These ideas formed the basis for Wilson and Kelling's broken windows theory (Wilson \& Kelling, 1982), namely that disorder in one area attracts more crime. The simplistic link between economic vulnerability, disorder and crime was later contested. In the 1990s, Sampson and colleagues showed that people's ability to work for a common good, despite levels of cohesion, was also important for preventing crime. These ideas formed the basis of the collective efficacy theory (Sampson et al., 1997).

Both theories (social disorganization theory and collective efficacy) have been applied to explain why some residential areas differ in their amount of crime, but the theories failed to explain why specific places in a particular area become crime places. They also failed in considering individuals' modern lifestyles and patterns of daily mobility and communication. Individuals allow themselves to be affected by the environment as they spend different amounts of time in different places (where they reside, work or are in transit) with varying criminogenic properties. The decisions that individuals take to be on the move may result in a reduction of their safety, depending on where and how they travel. The importance of the quality of the environment while one is in transit will be further discussed in the next section.

\subsection{The movement}

Individuals' activities and daily habits are rhythmic (comprised of repetitive patterns in different parts of the city), which in turn affects patterns of crime. Crimes occur when individuals are waiting for a bus, traveling on some means of transportation or walking to a station. They may be unfamiliar with the risks of becoming a crime victim as they may be navigating an unknown environment or during risky hours. But when and where does most crime happen?

The criminologists Lawrence Cohen and Marcus Felson suggest that crime takes place when a motivated offender and a suitable target (victim or property) meet in time and space, without the presence of a capable guardian (Cohen \& Felson, 1979). By adopting principles of rational choice theory (Becker, 1968) and assuming that criminals act rationally (which is not always the case), one can state that a crime occurs when the conditions are such that the benefits to them of a crime outweigh the costs, suggesting that a lack of guardianship is a crucial element influencing where/when certain offences occur. A capable guardian, for instance, acts through his presence to prevent crime and through his absence to make crime more likely to occur, while motivated criminals do not search through a whole city for targets; they look for targets within their more restricted awareness space (Brantingham \& Brantingham, 1984).

Following crime pattern theory, the awareness space of an individual is composed of his or her "anchor points" in the urban landscape, such as place of residence, school and frequently used subway stations and transit lines connecting these anchor points. It is the interaction of the location of potential targets and the criminal's awareness or activity space that culminate in particular patterns of crime occurrence. Yet, the urban environment does not affect 


\section{Vania Ceccato}

individuals equally. First, individuals differ from one another. Second, the environment differs from place to place, and individuals are bound to react differently to different environments. As Wikström, Mann, and Hardie (2018) suggest, crime can be viewed not simply as the product of deep social, economic and psychological causes but also as the result of deliberate choices by individuals reacting to particular environmental circumstances.

A public place can generate thousands of crime opportunities, some more obvious to potential offenders or crime-prone individuals (those individuals that would consider crime as an alternative, based on their morality and self-control) than to anybody else. Yet, crime opportunities are neither uniformly nor randomly distributed in space and time (Ratcliffe, 2010). Temporal variations of crime are related to people's routine activity. They do follow rhythmic patterns of human activity, some varying daily, others weekly or seasonally. A target, a motivated offender and a capable guardian must converge in (public) place and time for crime to occur (Cohen \& Felson, 1979) as previously suggested, but such interaction is not enough to explain why a public place becomes a crime place.

A crime is an outcome of a perception choice process initiated by the interaction between the individual's crime propensity and his or her exposure to a criminogenic place (Wikström, Ceccato, Hardie, \& Treiber, 2010). According to situational action theory, a place "may become criminogenic when activities and users encourage behavioral norms that conflict with the law, and/or they are ineffective at enforcing the law" (Wikström \& Treiber, 2017, p. 82). Crime depends on the moral norms of a particular place, which in turn "depend on what kinds of activities take place within them and what kinds of people tend to be present, both of which are likely to vary by time of day, week and/or year" (Wikström \& Treiber, 2017, p. 82).

Therefore, the environment has a role to play in affecting a place's behavioral norms through the way it is designed and maintained, how it is used through the day by residents and visitors and how well it is interlinked to the rest of the neighborhood and city. Yet, according to Wikström et al. (2018), only when a crime-prone individual spends enough time in a criminogenic setting may a crime occur. To better prevent crime, one must better understand why a particular environment becomes criminogenic in the first place. A first step is to change public places that concentrate the most crimes; as described below, they are not criminogenically homogeneous: some attract crime, others absorb or radiate crime.

\section{Criminogenic public places}

We know that crime is six times more concentrated in places than among people (Weisburd \& Telep, 2011) and that most places have no crime (Eck, 1998; Sherman et al., 1989; Weisburd, Bushway, Lum, \& Yang, 2004). If an area offers shopping, recreation and restaurants, this area is bound to have a higher crime rate than residential areas just because it contains multiple "risky 
facilities" (Clarke \& Eck, 2007). For instance, about 60 percent of all crimes reported to the police in Stockholm occur within 500 meters of a metro station (Ceccato, 2012b; Ceccato, Uittenbogaard, \& Bamzar, 2011), and 10 percent of crimes that have happened in a shopping mall are concentrated in a particular part of the facility (Ceccato, Falk, Parsanezhad, \& Tarandi, 2018).

A public place is often a risky place, a place that concentrates a disproportionately high amount of crimes in relation to its surroundings (Clarke \& Eck, 2007). Some places will attract crime from the surrounding areas, others will generate crime. The types of interaction such a public place has with its surroundings and city contexts will determine its nature as a criminogenic place.

According to Brantingham and Brantingham (1995), a public place can be a crime generator, a place with many criminal opportunities that are well known to criminals; for example, a hidden spot outside a transit station can provide the perfect place for selling drugs.

A public place can also be a crime attractor; for example, a shopping mall or a bus stop may attract large numbers of people for reasons unrelated to criminal motivation, creating many opportunities for crime (Groff \& McCord, 2012; Hilborn, 2009; Iqbal \& Ceccato, 2015).

A busy public toilet may concentrate disorder and damage to public property and become a crime enabler (Clarke \& Eck, 2005), when rules of conduct are absent or are not enforced by users or place managers.

Bowers (2014, p. 389) explored the nature of the relationship between crimes occurring within a particular public place and those occurring outside but near the place and found that such a public place can become a crime radiator or crime absorber (Bowers, 2014). Crime radiators "cause crime in the immediate environment as well as internally", while crime absorbers absorb risk from the external locale.

As discussed in Section 2.3, place managers are important because they can contribute to the safety of the public spaces by exercising control over users (Eck, 2019), but these key actors are not alone. Felson (2006) suggests that multiple actors exercise social control: the "place manager" is the person responsible for controlling the behavior in a particular place, such as a teacher in a school or a security guard in a shopping center or a station. Then there is the "handler", who controls the individual (parent, sibling) who may be considering crime as an alternative, and finally the "capable guardian", who can protect the target, either a property or a person. As for targets, there are two types of guardians: formal guardians whose responsibility is to protect people and property from crime, such as police officers and security guards, and informal guardians, including friends and others who are at the same place as the target. A thief may give up stealing a purse if (s)he notices that (s)he is being watched by people on the bench or by the restaurant owner.

A limitation of this approach of focusing on where most crimes occur is that it often takes only the crime scene into account. Research by police officer Tamara Herold and her colleagues in the United States shows that the crime dynamics can be better understood through information about "where" and 


\section{Vania Ceccato}

"when" criminal networks socialize before a crime takes place (Madensen, Herold, Hammer, \& Christenson, 2017). They suggest that "comfort places" (e.g., a corner of a street where criminals hang out) play an important role in criminal proceedings although they are not crime scenes. Another limitation is that the detection of crime concentrations is scale dependent and works best in larger urban centers. In other words, this approach is less informative of the dynamics of crime of public places in rural contexts or smaller municipalities, simply because rural communities do not have enough risky facilities to generate or spread crime as larger urban areas have.

\subsection{The users' perspective}

An individual's risk perception often reflects something other than the likelihood of being a victim of crime. Koskela and Pain (2000) suggest that we create mental maps of feared environments and unsafe places based on our prior experiences as well as on media stories and the accounts of others. Sandercock (2005) argues that expressions of fear of crime are actually fear of others.

Fear, according to Warr (2000, p. 453), is "an emotion, a feeling of alarm or dread caused by awareness of expectation of danger". Jackson and Gray (2010) distinguish between "functional" and "dysfunctional" fear. Functional fear leads to precautionary actions that reduce both fear and risk of victimization, while dysfunctional fear leads to negative impacts on individuals, such as constrained mobility and avoidance of public spaces, as discussed in Parts III and IV of this book, affecting individuals' health and the overall sustainability of a place. A safe city is a sustainable city, one that allows living without the risk of being a victim of crime or fear of victimization.

By tradition, women describe themselves as feeling more fear in urban environments than men (Pain, 2000), partly because men and women use and experience such environments in different ways (Dymén \& Ceccato, 2012). However, we must not believe that an individual's safety is based solely on gender. Several individual factors determine the risk of victimization as well as safety perceptions. Women, the elderly, members of ethnic minority groups, those who belong to the LBTQTI community, those with disabilities and those who are disadvantaged report higher levels of fear of crime (Box, Hale, \& Andrews, 1988; Garofalo \& Laub, 1979; Pain \& Smith, 2008).

Disability affects vulnerability to crime (Iudici, 2015; Iudici, Bertoli, \& Faccio, 2017). In Stockholm city, for example, those who feel that they have one or more disabilities state twice as much fear of being victims of assault and robbery than the general population. Three times as many say they were worried or do not go out after dark where they live because they are afraid of being exposed to crime (Ceccato, 2013b). However, although men are victims of reported crime while in transit more often than women are (Morgan \& Smith, 2006), women declare being more fearful than men (Ceccato, 2013b; Dymén \& Ceccato, 2012). Similarly, while young people are statistically more 
at risk of being victimized, older and/or disabled individuals tend to be more fearful (Furstenberg, 1971; Lagrange \& Ferraro, 1989). In sum, it is fundamental to consider the intersection of multiple individual factors (e.g. age, gender, disability) when assessing differences in individual's risk of victimization and safety perceptions.

Environmental factors in public places contributing to fear include dark environments, poor guardianship, lack of maintenance, physical and social disorder, and unkempt and abandoned buildings (Loukaitou-Sideris 2009, see also Chapter 3 in this book). This is problematic not only because signs of physical deterioration are often visible in public places but also because these nuisances are able to capture a much broader range of problems (Skogan, 1996). Paradoxically, the presence of police may generate uneasy feelings (Gray, 2015). In addition, some potential local and global dangers may mediate fear and vulnerability in modern societies (Beck, 1992). All these interlayers of factors lead to more fear and limit individuals' mobility, often creating borders and more control of public places, with more negative consequences to those who use them.

\subsection{The metrics}

Almost everything that happens, happens somewhere (Longley et al., 2005), so knowing where a phenomenon takes place can be critically important to understanding its nature and acting upon it. This is particularly important to those whose responsibility is to assess or ensure safety conditions in cities (Ceccato, 2013a; Weisburd, Bruinsma, \& Bernasco, 2009). Research shows a vast number of techniques and methods that can be used to detect safety problems, either for finding crime concentration or areas perceived as unsafe. Some methods are more appropriate for intervention and assessment, while others require the long-term involvement of relevant stakeholders, such as safety walks and neighborhood watch initiatives. See Section 2.7 for a detailed discussion of these methods.

New technologies can provide a nuanced understanding of use of public places in relation to crime and perceived safety (Ceccato, 2019). Ecological momentary assessments (EMAs) are a data collection method in which information about individuals' experiences, emotions and behaviors is collected in real time via smart devices as individuals go about their lives (Raento, Oulasvirta, \& Eagle, 2009).

In the era of smartphones, "eyes" are complemented by "apps" or body cameras, giving expression to new ways of depicting what happens in public space. This development is bound to redefine what social control is, in particular the role of guardians and place managers, but also how we detect and assess a safety problem. In Chapter 15 of this book, this digital methodology is exemplified to assess fear while in transit. Commonly used are apps, virtual reality (VR) and building information modeling (BIM). An app is a mobile application, for mobile devices such as smart phones and tablets, while VR is computer technology that simulates real or fictional environments and our presence and interaction in them. There are also other digital solutions that can be implemented when an area is being built. For instance, BIM is a process that 
creates and uses an intelligent 3D model to inform and communicate project decisions and to project, visualize, simulate and collaborate, which gives greater clarity to all stakeholders throughout the project lifecycle. BIM makes it easier to show at a micro scale where safety problems are (see, for instance, BIM in a shopping mall in Ceccato et al. 2018).

The introduction of computerized mapping systems as part of police command and control since the 1980s and 1990s has led to the creation of software for visualizing the growing amounts of geocoded crime data. In addition, geographic information systems (GIS) have made geographical analyses of crime data possible for a wide number of users, facilitating the integration of many types of data into a common spatial framework (Ceccato, 2013a). The use of spatial tools such as GIS has been incorporated into research and planning in public participation initiatives (see Part VI in this book) and, more recently, into new methodologies aiming at predicting human reactions about terrorism events using real-time data (see Chapter 17 for use of data from Twitter). In such cases, the digital arena is the new public place where crime may occur.

\subsection{The intervention}

Promoting safe and sustainable urban environments demands well-coordinated actions from multidisciplinary teams of experts (involving architects, planners, safety experts, police and policymakers, to name a few) and efforts from civil society. There are two distinct "time windows of action" for these groups of experts.

The first one is when a public place is at the planning stage. Architects, planners and safety experts, in particular, play important roles ensuring safe environments at this stage.

The second one is when the "city is already out there" and actions remediate "faulty" environments, namely those places that are contributing to crime and/ or poor perceived safety. The role of safety experts in teamwork-with police officers and local teams engaging different groups of the community-becomes perhaps more important than those of planners or architects at this stage. These time windows of intervention are discussed below in detail.

\section{Safety at the design and planning stage}

The first time window of action is when a (public) place is at the planning stage. This is a unique opportunity, since architects and planners in particular have the opportunity to idealize how buildings and the spaces between them should be designed. It is at this time they can make choices that can affect the future of the area to prevent crime and promote safety. The planning and design of public places (streets, tunnels, bridges, stations, parks and other spaces) are crucial, as are their location and spatial arrangement. At this stage, experts can apply their knowledge by creatively assembling "the building blocks of routine activity into the urban cloth" (Brantingham \& Brantingham 1995, p. 3) to 
maximize safety. This may include planning for details of the physical environment such as smooth boundaries between public, semi-private and private places; strengthening the experience of social control in particular spots, such as transportation nodes and shopping malls; designing buildings so that windows provide an opportunity for natural surveillance. Other features are also possible, such as promoting activities that generate the right amount of people on the street or finding the right balance between the benefits of double illumination in a square and energy savings. In reality, these experts work under the pressure of limited resources, strict building and planning regulations and demands from diverse special interests that wish to prioritize other aspects of the construction, such as energy savings or economic efficiency.

Proven methods and principles under the CPTED umbrella can support design and planning of buildings and public spaces to promote safety (Armitage, 2013; Grönlund, 2012; Jeffery, 1977; Newman, 1972; Saville, 2009). International evidence shows that these principles impact positively on safety. In England, research has shown that houses that are guarded by three or more other properties experienced 38 percent less crime (Armitage, 2013). This effect has been confirmed both in new production and in existing buildings, for crime and fear of crime, in the Netherlands (CVP 2015) and also in Korea (Seo \& Lee, 2017).

There is a growing body of research that supports the assertion that crime prevention through environmental design is effective in reducing both crime and fear of crime in the community (Ceccato \& Tcacencu, 2018; Cozens, Saville, \& Hillier, 2005; Cozens, Neale, Whitaker, Hillier, \& Graham, 2003; Kajalo \& Lindblom, 2010).

However, there are many barriers for the implementation of these safety guidelines in practice. In most countries, safety principles are not an integral part of new building projects. Construction companies often skip extra demands unless they are based on the requirements in a project for economic reasons. In Sweden, for instance, if safety issues are considered in the planning process of a new residential area, they often relate to traffic safety or fire hazards (see Chapter 21 of this book or Ceccato, Vasquez, Langefors, Canabarro, \& Petersson, 2019). Second, there is a concern and a risk about who is responsible for the process, which can produce variations in the delivery process-not only who delivers (police or civilians based in municipalities and/or consultants), but also how safety guidelines are implemented, thus resulting in a different impact on social groups using public places, for instance.

The need to find new ways of working and of improving knowledge among stakeholders concerning the impact of the urban environment on safety constitutes another barrier. While planners and architects see that crime and safety perceptions do not belong in their subject area, safety experts often focus too much on offenders and too little on the situational conditions of crime and safety, making this issue a neglected area in urban planning. 
Finally, as suggested by Wikström and Treiber (2017), interventions that specifically target environmental characteristics can only be effective in preventing crime if they promote changes in how people perceive crime as an alternative in the specific environment. This means that "building right" from the beginning is not enough. It also requires good and continuous maintenance after an area is built (see for example Branas et al., 2011), through dialogue with relevant stakeholders that takes into account different users' needs and demands on that particular place.

\section{Safety in pre-existing urban environments}

There are plenty of opportunities to improve safety when the city is already there. But how do we get there, how do we go from words to action? Planners, architects and safety experts often make use of principles of routine activity and situational crime prevention (Clarke, 1995; Cohen \& Felson, 1979) as theoretical references to tackle particular places (and times) that suffer disproportionately high crime levels.

Working in a team will make it easier to place a particular safety problem into local contexts, especially the needs of those who make use of that particular environment. Some of these problems are not visible to experts, and engaging with users and locals who know well the area is a good starting point. It is also important to calibrate the use of resources, knowledge and experience within the group for best results. For instance, check what collective experiences there are in the working group, if there is lack of knowledge that may be needed in the solution process and which actors are responsible for which areas of the process (Forsemalm, Johansson, \& Göransson, 2019).

A deep understanding of the nature of the safety problem (Figure 2.1) is fundamental. It is less obvious how current serious urban problems, such as violence and organized crime can be solved and how they create fear. Solutions demand more than "fixing the lighting or cutting bushes". Detecting the problem and analyzing it in detail is important (crime-specific, context-specific),

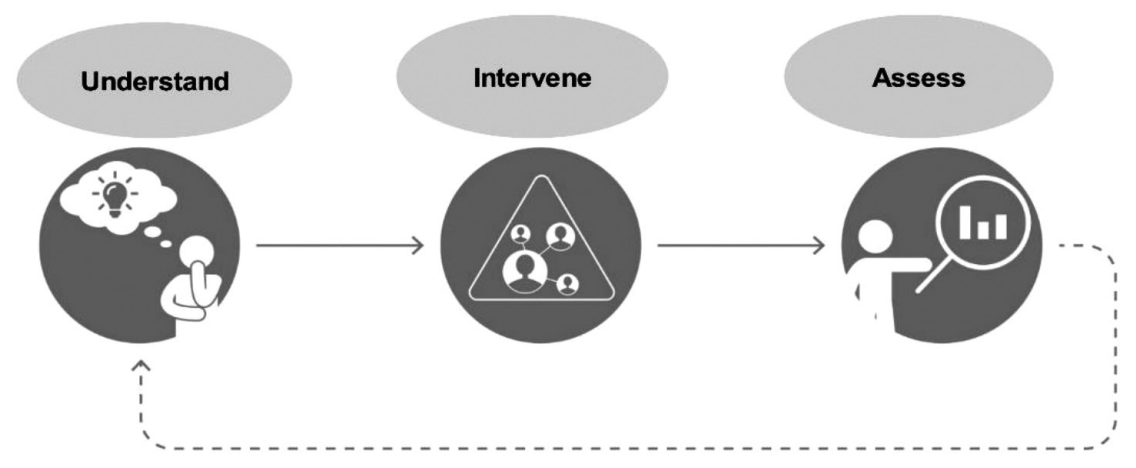

Figure 2.1 Safety interventions steps. 
both to obtain an accurate picture of the phenomenon and to be able to measure the outcome of future interventions using a "before and after" scenario. What is it in the environment that leads a person to commit crimes in that particular spot? What is it that generates feelings of worry and fear? Using recommendations from Clarke and Eck (2005), it is possible to further develop a number of questions to be answered at the beginning of the process before defining safety interventions.

What? Does the problem concern crime or perceived security? Is it a new area to be planned, or will an existing area be improved?

Where? Is the problem happening in a city or in the countryside? Is it in a residential area, in a square or in a building?

When? During which times of the day/days of the week/months of the year does the problem occur? Is it constant over time or does it vary?

Who? Who is badly affected by the problem, does it affect the entire population equally or are there specific groups - such as women, the elderly, children, the financially vulnerable-who are affected? Is there information about those who commit crimes and their modus operandi?

The answers to these questions will have a major impact on the choice of the solutions and are important to bring to light through the solution process. At this stage, major changes in the physical environment to improve safety may be costly and may not even be desirable because of negative impacts on the aesthetics of the place (grates in the windows and facades, fences around parks and squares, barriers that limit movement in street sections, in some cases, CCTVs for control and surveillance). Below is a list of a number of techniques and methods popularly used to detect safety problems and work with them.

Security certification: Quality control designed to reduce exposure to crime in residential properties. The verification is carried out using a checklist, which is primarily adapted to existing buildings and can be used in apartment buildings. The checklist may look different depending on whether it is applied in housing that already exists and has problems with crime and insecurity, or used to build a knowledge base when planning new housing and/or public environments.

Neighborhood watch: Various activities in an area aimed at improving residents' involvement, sense of participation and social affiliation and thus the social control that is fundamental to crime prevention and security. These activities (for example, informing neighbors to pay extra attention at times to who is moving around the area) are also expected to change the behavior of potential victims and thus reduce opportunities for crime.

Night patrol: Also called parental walking, adult walking, dads and moms in town or adults in town. Groups of adults move out on the streets and squares 
and into environments where young people stay in the evening and night time, in order to create a safer environment.

Social impact assessment: Packages for analyzing, monitoring and managing the intended and unintended social consequences, both positive and negative, of planned actions and any social change processes that result from these efforts (Vanclay, 2003). For example, a change in a city can have different consequences at different times of the day or have different consequences for different groups of people, which need to be made visible and taken into account in planning processes.

Safety walk: A group of people going through an area and systematically inventorying or inspecting it from a security standpoint, often with a fieldwork protocol in hand, in paper form or digitally using an app (Creswell, 2013, p. 168), although the "walk" can be virtual. During the inventory, locations and spaces that are perceived as unsafe or at risk of becoming crime sites are noted, as well as the specific physical circumstances that contribute to the problems. The process includes developing proposals for solutions, and the safety inventory can then form the basis for safety interventions.

Building improvement district: BID represents a collaboration scheme of local property owners in conjunction with local agencies (e.g., city offices, the police, the fire and rescue services, et al.).

Placemaking: This is a set of participatory approaches to planning, design and management of public places that engage individuals and communities into a process for transformation (Schneekloth \& Shibley, 1995). One example is creative placemaking, which is thought to contribute to livability of an area by addressing users' safety, aesthetic and expressive needs by using expressions of art and culture.

Once the working team understand a problem, it is time to intervene (Figure 2.1). One challenge with safety problems is to make sure that the measures being implementing also work as expected and do not have unwanted side effects. Relatively easy solutions, such as creating physical barriers may increase safety for some, but may be at the expense of other groups or the entire population. There are sometimes contradictions between sustainability goals; for example, good lighting in an area can make people safe but at the same time increase energy consumption, which contributes to global warming. There are expectations that safety interventions in the physical environment can be proportionate and weighed against the long-term vision for an area as well as other sustainability goals (Ceccato \& Pettersson, 2019).

Even at this stage, it is important to work systematically and with regard to detail; that is, each crime has its dynamics and requires specific measures. A prerequisite for this is to have a good understanding of the problem, to analyze and document what the situation was like before the intervention and the outcomes after changes were put into operation. This means, more specifically, that one must consider scale (a place or a residential area) and context (metropolitan context vs. smaller municipality). It is also important to prioritise and calibrate the use of resources, knowledge and experience of your team for best results during the intervention. 
It is fundamental to follow the same methods when evaluating the effects of the intervention. Also important is to keep in mind that the measures that have been implemented are probably not the only changes that have taken place during the period measured. Therefore, assessing the same measure in several places is desirable (Figure 2.1). Using control areas-where no action has been implemented-makes the results of the evaluation more reliable. A control area should have the same problem make-up as the areas where the measure is being tested. In this way, it shows what one would expect to have happened in the implementation area if no action was taken. Another reason to use a control area is that the effect of interventions can spread to a larger area than the one initially planned. This applies to both good and bad effects. For example, better lighting and maintenance in a public place can make the surrounding area also feel safer, but it can also mean, despite the fact that it does not happen so often, that the original feeling of poor safety is moved to another place. Keep in mind that it can take a long time for the results of actions to become clear, so if actions are evaluated too soon their effects may not be visible at the current time. It may also happen that the problems recur after the evaluation. Therefore, it is good to keep track of the area or place where measures have been implemented for a long time and to continuously assess the occurrence of crime and insecurity.

Moreover, the impact of an intervention is often not homogeneous in the study area. Of course, there are also examples of measures that have not worked at all, but if these have been evaluated, they need not be seen as total failures. Unexpected results are not necessarily "bad results" because they indicate that those interventions are not worth investing in the future, and resources can be spent on other measures.

By the same token, the fact that an action has a positive effect on a place for a certain period of time does not mean that the intervention will generate the same results elsewhere and should be used anywhere or at any time (with the same outcome). The context, as already mentioned, is of great importance: what works for a problem in a metropolitan context may not have the same effect on the same problem in sparsely populated areas. In real life, evaluation with control areas is not always possible, so triangulations of several qualitative assessments are good alternatives, for example through interviews, focus groups, photographs or safety walks before, during and after measures have been implemented. In the next chapters, and in particular in Chapters 18 to 21, examples of innovative methods (e.g., mapping, apps and Twitter data) are introduced to report safety interventions in a more nuanced way.

\subsection{Concluding remarks}

Crime happens in all sorts of public places: from crowded streets to desolate interstitial spaces between buildings; in large cities or small towns, some more in rush hours, others during the dark, quiet hours of the day. Some of these public places are dangerous but may be perceived as safe; others do not offer any kind of risk but may still be viewed as unsafe. In this chapter, the concept of 


\section{Vania Ceccato}

public places in relation to the dynamics of urban crime and fear was discussed. Then, theories describing the mechanisms linking crime and fear with the built environment were analyzed in relation to the role of architects, planners and safety experts. This was followed by theories describing the nature of fear, with particular focus on the fear of crime and those who are most victimized or most in fear. The chapter ends by presenting methods of analysis regarding safety problems and how safety interventions are put into practice. This review also shows that a large number of models of safety interventions have been suggested in the last decades in an attempt to fill the void in knowledge (and action) of researchers and practitioners in recognizing the importance of the physical and social environment to safety. Who delivers safety interventions is also relevant to ensuring all needs are considered. "Building right" from the beginning is not enough. In areas that already exist, focusing on specific problems is fundamental, as is making sure that assessments of safety interventions are systematically performed. Finally, it is important to have a long-term perspective of the safety of an area-one that accepts that the area is in continuous transformation and that safety needs may be changing.

\section{Note}

1 Instead of weighing the multiple ways we can conceptualize public place and public space, we chose to use these terms interchangeably in this book, extending the concept to public places that are digital, as illustrated in Chapters 1 and 17. For a brief definitional discussion of public places and crime, see Ceccato (2016).

\section{References}

Alexander, D., Ishikawa, S., \& Silverstein, M. (1977). A Pattern Language: Towns, Buildings, Construction. USA: Oxford University Press.

Armitage, C. J., \& Ekblom, P. (2019). Rebuilding Crime Prevention Through Environmental Design: Strengthening the Links with Crime Science. Abingdon: Routledge.

Armitage, R. (2013). Crime Prevention through Housing Design: Policy and Practice. Basingstoke, UK: Palgrave Macmillan.

Armitage, R. (2018). Burglars' take on crime prevention through environmental design (CPTED): reconsidering the relevance from an offender perspective. Security Journal, 31, 285-304.

Armitage, R., \& Monchuk, L. (2011). Sustaining the crime reduction impact of designing out crime: re-evaluating the Secured by Design scheme 10 years on. Security Journal, 24, 320-343.

Asiedu, A. B., \& Arku, G. (2009). The rise of gated housing estates in Ghana: empirical insights from three communities in metropolitan Accra. Journal of Housing and the Built Environment, 24, 227-247.

Barker, R. (1968). Ecological Psychology Concepts and Methods for Studying the Environment of Human Behaviour. Stanford: Stanford University Press.

Beck, U. (1992). Risk Society: Towards a New Modernity. London: Sage.

Becker, G.S. (1968). Crime and punishment: an economic approach. The Journal of Political Economy, 76(2), 169-217.

Bowers, K. (2014). Risky facilities: Crime radiators or crime absorbers? A comparison of internal and external levels of theft. Journal of Quantitative Criminology, 30, 389-414. 
Box, S., Hale, C., \& Andrews, G. (1988). Explaining fear of crime. British Journal of Criminology, 28, 340-356.

Branas, C. C., Cheney, R. A., MacDonald, J. M., Tam, V. W., Jackson, T. D., \& Ten Havey, T. R. (2011). A difference-in-differences analysis of health, safety, and greening vacant urban space. American Journal of Epidemiology, 174, 1296-1306.

Branic, N., \& Kubrin, C. E. (2018). Gated communities and crime in the United States. In G. Bruinsma \& S. D. Johnson (Eds.), The Oxford Handbook of Environmental Criminology (Vol. 1). New York: Oxford University Press.

Brantingham, P. J., \& Brantingham, P. L. (1984). Patterns in Crime. New York: Macmillan.

Brantingham, P. L., \& Brantingham, P. J. (1995). Criminality of place: crime generators and crime attractors. European Journal on Criminal Policy and Research, 3, 1-26.

Breetzke, G. D., Landman, K., \& Cohn, E. G. (2014). Is it safer behind the gates? Crime and gated communities in South Africa. Journal of Housing and the Built Environment, $29,123-139$.

Ceccato, V. (2012a). The Urban Fabric of Crime and Fear. Dordrecht Netherlands; New York; London: Springer.

Ceccato, V. (2012b). Vilken betydelse har miljön för trygghet och säkerhet på Stockholms tunnelbana? PLAN, 1, 39-43.

Ceccato, V. (2013a). Integrating geographical information into urban safety research and planning. Proceedings of the Institution of Civil Engineers: Urban Design and Planning, 166, 15-23.

Ceccato, V. (2013b). Moving Safely: Crime and Perceived Safety in Stockholm's Subway Stations. Plymouth: Lexington.

Ceccato, V. (2016). Public space and the situational conditions of crime and fear. International Criminal Justice Review, 26, 69-79.

Ceccato, V. (2019). Eyes and apps on the streets: from surveillance to sousveillance using smartphones. Criminal Justice Review, 44, 25-41.

Ceccato, V., Falk, Ö., Parsanezhad, P., \& Tarandi, V. (2018). Crime in a Scandinavian shopping centre. In A. R. Ceccato V. (Ed.), Retail Crime: International Evidence and Prevention: Cham: Palgrave Macmillan.

Ceccato, V., \& Pettersson, R. (2019). Tryggstadsmiljön i praktiken: Visioner, exempel och tips. www.kth.se/files/view/vace/5dc3a43c38cal004b7abb8el/trygg-stadsmiljoe-i-praktiken_ v.pdf (accessed 20 January 2020).

Ceccato, V., \& Tcacencu, S. (2018). Perceived safety in a shopping centre: a Swedish case study. In V. Ceccato \& R. Armitage (Eds.), Retail Crime: International Evidence and Prevention (pp. 215-242). Cham: Springer International Publishing.

Ceccato, V., Uittenbogaard, A., \& Bamzar, R. (2011). Safety in Stockholm's underground stations: the importance of environmental attributes and context. Security Journal, 26, 33-59.

Ceccato, V., Vasquez, L., Langefors, L., Canabarro, A., \& Petersson, R. (2019). En trygg stadsmiljö: Teori och praktik för brottsförebyggande \& trygghetsskapande åtgärder. Retrieved from Stockholm: http://kth.diva-portal.org/smash/get/diva2:13 58155/FULLTEXT01.pdf (accessed 20 January 2020).

Chase, J. (2008). Their space: security and service workers in a Brazilian gated community. Geographical Review, 98, 476-495.

Clarke, R. C., \& Eck, J. E. (2005). Crime analysis for problem solvers in 60 small steps. Retrieved from www.semanticscholar.org/paper/Crime-Analysis-for-Problem-Solversin-60-Small-Clarke-Eck/be59dec7e23070bf8857745e737d9f4c90aeff5e (accessed 18 April 2020)

Clarke, R., \& Eck, J. (2007). Understanding Risky Facilities. Tool Guide No. 6. Retrieved from https://popcenter.asu.edu/content/understanding-risky-facilities (accessed 20 January 2020). 


\section{Vania Ceccato}

Clarke, R. V. (1995). Situational crime prevention. Crime and Justice, 19, 91-150.

Clutter, J. E., Henderson, S., \& Haberman, C. P. (2019). The impact of business improvement district proximity on street block robbery counts. Crime \& Delinquency, doi:10.1177/0011128719834559.

Cohen, L. E., \& Felson, M. (1979). Social change and crime rate trends: a routine activity approach. American Sociological Review, 44, 588-608.

Coleman, A. (1985). Utopia on Trial. Vision and Reality in Planned Housing. London: Hillary Shipman.

Cozens, P., \& Hillier, D. (2008). The shape of things to come: New urbanism, the grid and the Cul-De-Sac. International Planning Studies, 13, 51-73.

Cozens, P. M. (2011). Urban planning and environmental criminology: towards a new perspective for safer cities. Planning Practice and Research, 26, 481-508.

Cozens, P. M., Neale, R. H., Whitaker, J., Hillier, D., \& Graham, M. (2003). A critical review of street lighting, crime and fear of crime in the British city. Crime Prevention and Community Safety, 5, 7-24.

Cozens, P. M., Saville, G., \& Hillier, D. (2005). Crime prevention through environmental design (CPTED): a review and modern bibliography. Property management, $23(5), 328-356$.

Creswell, J. W. (2013). Qualitative Inquiry o Research Design: Choosing among Five Approaches. Thousand Oaks, CA: Sage.

Crowe, T. (2000). Crime Prevention Through Environmental Design: Applications of Architectural Design and Space Management Concepts. Oxford: ButterworthHeinemann.

CVP, Centrum voor Criminaliteitspreventie en Veiligheid (2015). Bestaande bouw Handboek Politiekeurmerk Veilig Wonen. Retrieved from www.kiwa.com/contentassets/a5e877747a6c4dbea77ff0698c220536/pkvw-handboek-bestaande-bouw-2015. pdf (accessed 11 December 2019).

Dymén, C., \& Ceccato, V. (2012). An international perspective of the gender dimension in planning for urban safety. In V. Ceccato (Ed.), The Urban Fabric of Crime and Fear (pp. 311-341). Dordrecht, Heidelberg, New York, London: Springer.

Eck, J. (1998). Preventing crime at places. In: Preventing Crime: What Works, What Does Not, What's Promising. Retrieved from www.ncjrs.gov/works/index.htm.

Eck, J. E. (2019). Place Managers and Crime Places. Oxford: Oxford University Press, doi: 10.1093 /acrefore/9780190264079.013.30

Felson, M. (2006). Crime and Nature. Thousand Oaks: Sage.

Forsemalm, J., Johansson, M., \& Göransson, P. (2019). Evidensbaserad stadsutvecklingbortom urbana anedokter. Årsta: Dokument Press.

Furstenberg, J. F. F. (1971). Public reaction to crime in the streets. The American Scholar, 40, 601-610.

Garofalo, J., \& Laub, J. (1979). Fear of crime-broadening our perspective. Victomology, $3,242-253$.

Goold, B., Loader, I., \& Thumala, A. (2010). Consuming security?: Tools for a sociology of security consumption. Theoretical Criminology, 14, 3-30.

Gray, F. (2015). The misanthropes, larrikins and mallrats of Market Square: an enduring public space dilemma in Central Geelong. In SAHANZ 2015: Architecture Institutes and Change. Proceedings of the 32nd Annual Conference of Society of Architectural Historians Australia and New Zealand. (pp. 218-230). Society of Architectural Historians Australia and New Zealand.

Gray, F., \& Novacevski, M. (2015). Unlawful acts, unkind architecture and unhelpful perceptions: A case study of Market Square Mall, Geelong. In Proceedings of the Safe Cities Conference 2015 (pp. 4-18). Association for Sustainability in Business. 
Groff, E., \& McCord, E. S. (2012). The role of neighborhood parks as crime generators. Security Journal, 25, 1-24.

Grundström, K. (2018). Grindsamhälle: the rise of urban gating and gated housing in Sweden. Housing Studies, 33, 18-39.

Grönlund, B. (2012). Is hammarby sjöstad a model case? Crime prevention through environmental design in Stockholm, Sweden. In V. Ceccato (Ed.), The Urban Fabric of Crime and Fear (pp. 283-310). Dordrecht: Springer Netherlands.

Hilborn, J. (2009). Dealing with crime and disorder in urban parks. Retrieved from www.cops.usdoj.gov (accessed 14 April 2012).

Hillier, B. (1986). City of Alice's dreams. Architects' Journal, 9, 39-41.

Iqbal, A., \& Ceccato, V. (2015). Does crime in parks affect apartment prices? Journal of Scandinavian Studies in Criminology and Crime Prevention, 16, 97-121.

Iudici, A. (2015). Sexual harassment against people with mental disabilities in transit environments: implications for services and clinics. In V. Ceccato \& A. Newton (Eds.), Safety and Security in Transit Environments: An Interdisciplinary Approach (pp. 328-343). London: Palgrave Macmillan UK.

Iudici, A., Bertoli, L., \& Faccio, E. (2017). The 'invisible' needs of women with disabilities in transportation systems. Crime Prevention and Community Safety, $19,264-275$.

Jackson, J., \& Gray, E. (2010). Functional fear and public insecurities about crime. British Journal of Criminology, 50, 1-22.

Jacobs, J. (1961). The Death and Life of Great American Cities. New York: Vintage Books.

Jeffery, C. R. (1977). Crime Prevention through Environmental Design. (2nd ed.). Beverly Hills: Sage.

Jongejan, A., \& Woldendorp, T. (2013). A successful CPTED approach: the Dutch 'Police Label Secure Housing'. Built Environment (1978-), 39, 31-48.

Kajalo, S., \& Lindblom, A. (2010). The perceived effectiveness of surveillance in reducing crime at shopping centers in Finland. Property Management, 28(1), 47-59.

Kang, J. H. (2011). Participation in the community social control, the Neighborhood Watch groups: individual and neighborhood-related factors. Crime \& Delinquency, 61, 188-212.

Kornhauser, R. (1978). Social sources of Delinquency. Chicago: University of Chicago Press.

Koskela, H., \& Pain, R. (2000). Revisiting fear and place: women's fear of attack and the built environment. Geoforum, 31, 269-280.

Lagrange, R. L., \& Ferraro, K. F. (1989). Assessing age and gender differences in perceived risk and fear of crime. Criminology, 27, 697-720.

Lemanski, C. (2006). Residential responses to fear (of crime plus) in two Cape Town suburbs: implications for the post-apartheid city. Journal of International Development, $18,787-802$.

Longley, P. A., Goodchild, M. F., Maguire, D. J., \& Rhind, D. W. (2005). Geographic Information Systems and Science. Chichester, UK: John Wiley.

Loukaitou-Sideris, A. (2009). What brings children to the park? Analysis and measurement of the variables affecting children's use of parks. Journal of the American Planning Association, 76, 89-107.

Loukaitou-Sideris, A. (2012). Safe on the move: the importance of the built environment. In V. Ceccato (Ed.), The Urban Fabric of Crime and Fear (pp. 85-110). Dordrecht: Springer Netherlands.

Madensen, T. D., Herold, M., Hammer, M. G., \& Christenson, B. R. (2017). Place-based investigations to disrupt crime place networks. Police Chief Magazine, Washington, DC. 


\section{Vania Ceccato}

McCarthy, J., \& Doyle, M. (2011). Business improvement districts and conservation-led regeneration. Urban Research and Practice, 4, 175-192.

Mihinjac, M., \& Saville, G. (2019). Third-generation Crime Prevention Through Environmental Design (CPTED). Social Sciences, 8, doi:10.3390/socsci8060182.

Mikellides, B. (2007). Theory, practice and education: architectural psychology 1969-2007. Journal of Learning and Teaching, 2(2).

Morgan, R., \& Smith, M. J. (2006). Crimes against passengers: theft, robbery, assault and indecent assault. In D. B. C. M. J. Smith (Ed.), Secure and Tranquil Travel: Preventing Crime and Disorder on Public Transport (pp. 77-102). London: Jill Dando Institute of Crime Science.

Newman, O. (1972). Defensible Space-Crime Prevention through Urban Design. New York: Collier Books.

Pain, R. (2000). Place, social relations and the fear of crime: a review. Progress in Human Geography, 24(3), 365-387.

Pain, R., \& Smith, S. J. (2008). Fear: critical geopolitics and everyday life. In R. Pain \& S. J. Smith (Eds.), Fear: Critical Geopolitics and Everyday Life (pp. 1-24). Aldershot: Ashgate.

Poyner, B. (1986). A Model for Action: Situational Crime Prevention. London: Her Majesty's Stationery Office.

Poyner, B. (1991). Situational crime prevention in two parking facilities. In R. V. Clarke (Ed.), Situational Crime Prevention-Successful Case Studies (pp. 157-166). USA: Lynne Rienner Publishers.

Poyner, B. (2005). Crime-free Housing in the 21st Century. London, UK: Jill Dando Institute of Crime Science.

Raento, M., Oulasvirta, A., \& Eagle, N. (2009). Smartphones: an emerging tool for social scientists. Sociological Methods \& Research, 37, 426-454.

Ratcliffe, J. (2010). Crime mapping: spatial and temporal challenges. In A. R. Piquero \& D. Weisburd (Eds.), Handbook of Quantitative Criminology (pp. 5-24). New York: Springer.

Reynald, D. M. (2014). Informal guardianship. In G. Bruinsma \& D. Weisburd (Eds.), Encyclopedia of Criminology and Criminal Justice (pp. 2480-2489). New York: Springer New York.

Sampson, R. J., Raudenbush, S. W., \& Earls, F. (1997). Neighborhoods and violent crime: a multilevel study of collective efficacy. Science, 277(5328), 918-924.

Sandercock, R. J. (Ed.) (2005). Difference, Fear and Habitus, a Political Economy of Urban Fear. Aldershot: Ashgate.

Saville, G. (2009). SafeGrowth: moving forward in neighbourhood development. Built Environment (1978-), 35, 386-402.

Saville, G. (2018). Safegrowth: Building Neighbourhoods of Safety and Livability. Charleston: CreateSpace.

Schneekloth, L. H., \& Shibley, R. G. (1995). Placemaking: The Art and Practice of Building Communities. New York: Wiley.

Seo, S. Y., \& Lee, K. H. (2017). Effects of changes in neighbourhood environment due to the CPTED project on residents' social activities and sense of community: a case study on the Cheonan Safe Village Project in Korea. International Journal of Urban Sciences, 21, 326-343.

Shaw, C. R., \& McKay, H. D. (1942). Juvenile Delinquency and Urban Areas. Chicago: University of Chicago Press.

Sherman, L. W., Gartin, P. R., \& Buerger, M. E. (1989). Hot spots of predatory crime: Routine activities and the criminology of place. Criminology, 27(1), 27-56.

Skogan, W. G. (1996). The police and public opinion in Britain. American Behavioral Scientist, 39, 421-432. 
Sommer, R. (1972). Design Awareness. Corte Madera: Reinhart Press.

Symes, M., \& Steel, M. (2003). Lessons from America: the role of business improvement districts as an agent of urban regeneration. The Town Planning Review, 74, 301-313.

Tedong, P. A., Grant, J. L., \& Abd Aziz, W. N. A. W. (2014). The social and spatial implications of community action to enclose space: guarded neighbourhoods in Selangor, Malaysia. Cities, 4l(PA), 30-37.

Thomlinson, R. (1969). Urban Structure the Social and Spatial Character of Cities. Toronto: Random House Publishing.

Uhnoo, S., \& Hansen Löfstrand, C. (2018). Voluntary policing in Sweden: media reports of contemporary forms of police-citizen partnerships. Journal of Scandinavian Studies in Criminology and Crime Prevention, 19, 41-60.

Vanclay, F. (2003). International principles for social impact assessment. Impact Assessment \& Project Appraisal, 21, 5-11.

Warr, M. (2000). Fear of crime in the United States: avenues for research and policy. Criminal Justice and Behavior, 4, 451-489.

Weisburd, D. (2015). The law of crime concentration and the criminology of place. Criminology, 53, 133-157.

Weisburd, D., Bruinsma, G. J. N., \& Bernasco, W. (2009). Units of analysis in geographic criminology: Historical development, critical issues, and open questions. In D Weisburd, G. J. N. Bruinsma, W. Bernasco (Eds.), Putting Crime in its Place: Units of Analysis in Geographic Criminology (pp. 3-31). New York: Springer New York.

Weisburd, D., Bushway, S., Lum, C., \& Yang, S. M. (2004). Trajectories of crime at places: a longitudinal study of street segments in the city of Seattle. Criminology, $42,283-321$.

Weisburd, D., \& Telep, C. (2011). The efficiency of place based policing. In E. D. E. De Vree, W. Broer, P. Van der Laan (Eds.), Evidence Based Policing (pp. 247-262). Antwerpen, Apeldoorn, Portland: Maklu.

Whitzman, C. (2007). Stuck at the front door: gender, fear of crime and the challenge of creating safer space. Environment and Planning A, 39, 2715-2732.

Whitzman, C., Shaw, M., Andrew, C., \& Travers, K. (2009). The effectiveness of women's safety audits. Security Journal, 22, 205-218.

Wikström, P.-O., Ceccato, V., Hardie, B., \& Treiber, K. (2010). Activity fields and the dynamics of crime. Journal of Quantitative Criminology, 26, 55-87.

Wikström, P.-O. H., Mann, R. P., \& Hardie, B. (2018). Young people's differential vulnerability to criminogenic exposure: bridging the gap between people- and place-oriented approaches in the study of crime causation. European Journal of Criminology, 15, 10-31.

Wikström, P.-O. H., \& Treiber, K. (2017). Beyond risk factors: an analytical approach to crime prevention. In B. Teasdale \& M. S. Bradley (Eds.), Preventing Crime and Violence (pp. 73-87). Cham: Springer International Publishing.

Wilson, F. H. (1999). Fortress America: gated communities in the United States. [Fortress America: Gated Communities in the United States, Edward J. Blakely, Mary Gail Snyder]. Contemporary Sociology, 28, 83-84.

Wilson, J. Q., \& Kelling, G. L. (1982). Broken windows. Atlantic Monthly, 249, 29-38.

Yarwood, R., \& Edwards, B. (1995). Voluntary action in rural areas: the case of neighbourhood watch. Journal of Rural Studies, 11, 447-459. 